\title{
The Effect of Team Based Learning Model on Students' Critical Thinking Skills in Ecosystem
}

\author{
Mieke Miarsyah", Ratna Komala, Riska \\ Department of Biology Education, Faculty of Mathematics and Natural Science, Universitas Negeri Jakarta, Indonesia
}

Received October 19, 2019; Revised January 27, 2020; Accepted March 24, 2020

Copyright $@ 2020$ by authors, all rights reserved. Authors agree that this article remains permanently open access under the terms of the Creative Commons Attribution License 4.0 International License.

\begin{abstract}
21st century education must be able to develop the students' various skills, one of which is the critical thinking skill. Critical thinking skills are reasonable and comprehensive way of thinking that are used to make decisions. The aim of this study was to determine the effect of Team Based Learning (TBL) models on student critical thinking skills in Ecosystem. The research method used in this study was a Quasi Experimental Design method with pretest post test control group design. There are 60 students on each class selected through simplerandom sampling. The instruments used were 15 items about critical thinking, which have been declared valid and reliable. The result showed that the average critical thinking scores of students increased significantly by using Team Based Learning (TBL) model. The highest gain score in the experiment class on first aspect (Clearness) is in gain score of 0,7 (high). Mean while the smallest increase occurred in control class on aspect accuracy, relevance, breadth and precision in gain score of 0,0 (low). A t-test indicated that TBL students' critical thinking skills significantly increased (sigvalue. $0.00)$. The conclusion was that there was an influence on the application of the Team BasedLearning (TBL) model on students' critical thinking skills in Ecosystem.
\end{abstract}

Keywords Ecosystem, Critical Thinking Skills, Team Based Learning (TBL)

\section{Introduction}

Education in the 21st century must be able to prepare the students for having various skills to deal with many opportunities and challenges in life. Skills that must be possessed by the students in the 21st century such as creativity and innovation skills, critical thinking skills and problem solving, communication and collaboration, information literacy, media and information technology, flexibility and abilites to adapt, initiative, social and cross cultural abilities as well as productivity and accountability[6]. 21st century education has made learning change from teacher center to the student center. Student are not only asked to record everything that is explained by the teacher, but also actively seek various information from any sources [5,7,23].

Critical thinking is reasonable, reflective thinking that is focused on deciding what to believe or do [8]. In this digital era, students will get a lot of information easily and quickly but the truth of the information cannot be guaranteed.. Therefore, students must have the ability to think critically, because it will make it easier to choose relevant sources and information to make a decision [26].According to Facione people who have good critical thinking skills will have better self-confidence, deep knowledge, an open mind, able to see some alternative points of view in problem solving, strong beliefs in making a decision, able to make better judgement and consideration when making a decision [9]. Critical thinking skills are also a factor that can predict students cognitive learning out comes [16].

In biology learning specifically in Ecosystem topic, students really need critical thinking skills. This is because on this topic a lot of materials are not enough to memorize and remember. In detail, if we want to learn the role of organism in their ecosystem such as consumer or decomposer and the problem that will come if this organismis not in stablestage or extict, the critical thinking skills are required. This is because the topic has many problems that are relevant to daily life and must be solved by students [12]. Students will be required to make decision store solve existing problem quickly, precisely and accurately.

The fact is that students critical thinking skills have not been yet developed at school. Programmefor International 
StudentAssesment (PISA) 2018 shows Indonesia scienceliterationscoreis 396, it is lower than OECD rate [21]. It reflects that student's skills in answering questions referring tocritical, logical and problem solving skills place in low. The low critical thinking skills of students are caused by learning activities that tend to only practice aspects of remembering and understanding [17]. In these learning activities students tend to just sit and listen to the information presented by the teachers without being able to develop the information obtained or discuss it in class.

To solve the problem is by applying an active learning model that is able to invite students to process the information obtained and not just transfer the available information. One of them are Team Based Learning (TBL) model. This model refers to constructivism learning theory whereby knowledge will be formed from one's personal experience [19]. Michaelsen Larry defines Team Based Learning model as a conceptual and operational learning framework that relies on small group interactions to get concepts and problem solving [14]. The Team Based Learning model consists of six stages of learning, namely pre-class preparation, individual readiness assurance test, team readiness assurance test, appeals, mini lecture clarification and application.

Based on the purpose of this, the study improved the student critical thinking skills in Ecosystem using Team Based Learning (TBL) model.

\section{Methods}

The methodused in thisresearchwasQuasi Experiment with pretest posttest control group design. This research involved two groups. The experiment group was applied by Team Based Learning model (TBL) and the control group was applied by Student Team Achievement Divisions model (STAD). This research was conducted in second semesters of the 2018/2019 in 51 Jakarta senior highschool. The sample, which was selected by simply random sampling selected four classes in $10^{\text {th }}$ grade of science class, two classes as an experimental class and two classes as a control class. Participants of each class are 60 students.

The instrumentused was critical thinking skills test consisting of 15 items about ecosystemtopic. This instrument was given during the pre-test and post-test. The indicator of critical thinking used consisted of 7 aspects, namely Clearness, Accuracy, Relevance, Sufficiency, Depth, Breadthand Precision [18]. More details can be seen in table 1.

The data will be analyzed from the result of pretest and posttest of student's critical thinking skills on Ecosystem topic with the aim at knowing the difference average between the experimental and control classes. The different average that occurs proves that there is an effect of the treatment to students critical thinking skills. Before being analyzed, the data was tested for normality by kolmogorov - smirnov test and homogenity by Fisher's test. The hypotheses testis using t-test and all the tests are using a significant level $\alpha=0.05$ and calculated with SPSS version 23. The result of students critical thinking skills will be categorized into three categories, based on means and standard eviation categories adapted from Azwar in table 2.

Table 1. Indicator of Instrument

\begin{tabular}{|c|c|c|}
\hline Aspect & Indicator & items \\
\hline Clearness & $\begin{array}{l}\text { Provides thoughts that are easy to } \\
\text { understand accompanied by pictures, } \\
\text { examples or illustrations. }\end{array}$ & $5,10 a$ \\
\hline Accuracy & $\begin{array}{l}\text { Deliver information based on existing } \\
\text { data and facts. }\end{array}$ & $6 a, 6 b$ \\
\hline Relevance & $\begin{array}{l}\text { Give statements that are interrelated or } \\
\text { related between problems and problem } \\
\text { solving. }\end{array}$ & $2 a, 7 a$ \\
\hline Sufficiency & $\begin{array}{l}\text { Give reasons that match your goals } \\
\text { and needs. }\end{array}$ & $2 b, 4 b, 7 d$ \\
\hline Depth & $\begin{array}{c}\text { Identify the complexity or depthof a } \\
\text { problem }\end{array}$ & $1,4 a$ \\
\hline Breadth & $\begin{array}{c}\text { Identify a problem from various } \\
\text { interrelated viewpoints }\end{array}$ & 7c, 8a \\
\hline Precision & $\begin{array}{c}\text { Provide thoughts ori deas in detail and } \\
\text { specific. }\end{array}$ & 3,9 \\
\hline
\end{tabular}

Table 2. Category of Critical Thinking

\begin{tabular}{|c|c|}
\hline categories & criteria \\
\hline High & $\mathrm{X} \geq 65,46$ \\
\hline Moderate & $31,37 \leq \mathrm{X}<65,46$ \\
\hline Low & $\mathrm{X}<31,37$ \\
\hline
\end{tabular}

In addition, the gain scoreis also calculated to see the magnitude of the average increase in each aspect. After calculating the gain score, the next step was to categorize the gain score according o the criteria in Table 3.

Table 3. Criteria of Gain Score

\begin{tabular}{|c|c|}
\hline Gain Score & Criteria \\
\hline $\mathrm{g} \geq 0,7$ & High \\
\hline $0,7>\mathrm{g} \geq 0,3$ & Moderatae \\
\hline $\mathrm{g}<0,3$ & Low \\
\hline
\end{tabular}

The Team Based Learning (TBL) model consists of six stages of learning, namely preclass preparation, individual readiness assurance test (IRAT), teamreadinessassurancetest (TRAT), appeals, mini lecture clarification and application. More details can be seen in table 4. 
Table 4. Learning stages of Team Based Learning models.

\begin{tabular}{|c|c|}
\hline Stages & Descrition \\
\hline $\begin{array}{c}\text { Preclass } \\
\text { preparation }\end{array}$ & $\begin{array}{c}\text { Beginning of each major instructional unit, students are given reading and other assignments that should contain information } \\
\text { on the concepts and ideas that must be understood to be able to solve the problem you identified fort his unit in the backward } \\
\text { design activity }\end{array}$ \\
\hline $\begin{array}{c}\text { Individual } \\
\text { Readiness } \\
\begin{array}{c}\text { Assurance Test } \\
\text { (IRAT) }\end{array}\end{array}$ & $\begin{array}{c}\text { The first in-classactivity in eachinstructional unit isan individual Readiness Assurance Test (iRAT) over the material } \\
\text { contained in thepre-classassignments. The iRATsty pically consist of multiple-choice questions that, in combination, enable } \\
\text { the instructor to assess whether or not students have a sound understanding of the key concepts from the readings. }\end{array}$ \\
\hline $\begin{array}{c}\text { Team Readiness } \\
\text { Assurance Test } \\
\text { (TRAT) }\end{array}$ & $\begin{array}{c}\text { Students re-take the same test, but this time the teams must reach agreement on the answers to each test question and } \\
\text { immediately check the correctness of their decision using an IF-AT. }\end{array}$ \\
\hline $\begin{array}{c}\text { Appeals } \\
\text { missed on the group test. That is, students are allowed to do a focused re-study of the assigned readings (this phase is } \\
\text { "open-book") to "challenge" the teachers about their responses on specific items }\end{array}$ \\
\hline $\begin{array}{c}\text { Mini Lecture } \\
\text { Clarification }\end{array}$ & $\begin{array}{c}\text { This feedback comes immediately after the appeals process and allows the instructor to clear up any confusion students may } \\
\text { have about anyof the concepts presented in the readings. }\end{array}$ \\
\hline Application & $\begin{array}{c}\text { The final stage in the TBL instructional activity sequence for each unit of instruction is using one or more assignments that } \\
\text { provide students with the opportunity to deepen their understanding by having groups use the concepts to solve some sort of } \\
\text { problems }\end{array}$ \\
\hline
\end{tabular}

Source : Larry andMichelsen, 2011

Table 5. Students Critical Thinking Scores Viewed From Each Aspect

\begin{tabular}{|c|c|c|c|c|c|c|c|c|}
\hline & \multicolumn{4}{|c|}{ Average of control class } & \multicolumn{4}{c|}{ Average of Experiment class } \\
\cline { 2 - 10 } Aspect & post & pre & $\begin{array}{c}\text { gain } \\
\text { score }\end{array}$ & category & post & pre & $\begin{array}{c}\text { gain } \\
\text { score }\end{array}$ & category \\
\hline Clearness & 3,3 & 2,9 & 0,2 & low & 3,6 & 0,9 & 0,7 & high \\
\hline Accuracy & 3,8 & 3,8 & 0,0 & low & 3,0 & 1,2 & 0,5 & moderate \\
\hline Relevance & 2,2 & 2,1 & 0,0 & low & 2,9 & 1,0 & 0,5 & moderate \\
\hline Sufficiency & 2,8 & 2,3 & 0,2 & low & 3,4 & 1,2 & 0,6 & low \\
\hline Depth & 3,2 & 2,0 & 0,4 & moderate & 3,4 & 1,4 & 0,5 & low \\
\hline Breadth & 3,2 & 3,2 & 0,0 & low & 2,6 & 0,8 & 0,4 & low \\
\hline Precision & 2,7 & 2,7 & 0,0 & low & 3,3 & 1,5 & 0,5 & low \\
\hline
\end{tabular}

\section{Result and discussions}

The result of the research showed tha tall items are valid andreliable. The data was described in table. Data presented pre-test, post-test, gain scoreandcategoriesof student scritical thinking. Calculation of the gain scoreis the difference between the posttest and pretest. More canbeseen in table 5. In thetable 5. The largest increase can be seen from the gain score, which is in the experiment class on first aspect (Clearness) in gain score of 0,7 (high). Meanwhile the smallest increase occured in control class on aspect accuracy, relevance, breadth and precision in gain score of 0,0 (low). In experiment class there is one aspect that have high gain score (Clearness), twoaspects with moderate category (Relevance, Suffficiency) and anothe raspect in the low category. Meanwhile in controlclassthereisoneaspect in moderate category (Depth) and the other aspects are in low category. Thenthestudent critical thinking skills category can be seen from each test in Table 6.

Based on table 6 in experiment class students have a large increase in critical thinking skills. It can be seen that in pre-test there are 56 students in low category and 4 students in moderate category while in post test students in this class have a large increase. There are 42 students in moderate category and 18 students in high category. Meanwhile in control class there is a slight increase. In pretest here are 57 students in moderate category and 3 students in high category while in posttest here are 55 students in moderate category and 5 students in high category. This result indicates that both in experiment and control group have an increace in students critical thinking in Ecosystem topic.

The -test was conducted to test the significance of the difference between the experiment class and control class score. Significant test result showed the t-value is higher than t-table. In addition, if seen from Sig value $<0.05$, it can be concluded that the experimental class score is significantly higher than the control class. This can be interpreted that Team Based Learning (TBL) model scan enhancing students critical thinking skills in ecosystem topic. Details can be seen in table 7 . 
Table 6. Students Critical Thinking Skills Category

\begin{tabular}{|c|c|c|c|c|c|}
\hline \multirow{2}{*}{ categories } & criteria & \multicolumn{2}{|c|}{ Experiment } & \multicolumn{2}{c|}{ control } \\
\cline { 3 - 6 } & $\mathrm{X} \geq 65,46$ & $\begin{array}{c}\text { Pre } \\
\text { test }\end{array}$ & $\begin{array}{c}\text { Post } \\
\text { test }\end{array}$ & $\begin{array}{c}\text { Pre } \\
\text { test }\end{array}$ & $\begin{array}{c}\text { Post } \\
\text { test }\end{array}$ \\
\hline High & 0 & 18 & 3 & 5 \\
\hline Moderate & $31,37 \leq \mathrm{X}<65,46$ & 4 & 42 & 57 & 55 \\
\hline Low & $\mathrm{X}<31,37$ & 56 & 0 & 0 & 0 \\
\hline
\end{tabular}

Table 7. T-test result

\begin{tabular}{|c|c|c|c|c|}
\hline $\mathrm{t}$ & $\mathrm{df}$ & $\begin{array}{c}\text { Sig } \\
\text { (2-tailed) }\end{array}$ & $\begin{array}{c}\text { Mean } \\
\text { Difference }\end{array}$ & $\begin{array}{c}\text { Std. Error } \\
\text { Different }\end{array}$ \\
\hline 6.829 & 118 & .000 & 8,577 & 1.256 \\
\hline
\end{tabular}

Based on the result of the research it can be said that the Team Based Learning (TBL) models can enhance student critical thinking skills in Ecosystem topics. The results are consistent with the research conducted by Huggnis \&Jannet which shows that the use of Team Based Learning models can improve verbal abilities, creative thinking, and critical thinking skills of students [10].Team BasedLearning (TBL) model wasanactivelearning, in whichstudentscarryout a more in-depthinvestigationofthe material

studiedsothatstudentsthinkingskillsbecomemorehoned [19].

The effect of this learning model is caused by the learning stages used. First is the pre-class preparation. This stage will encourage students to be better prepared to learn in class so that the class discussion process can go well. This statement is supported by Jabbar., Et al who argues that preparation before learning will create an active learning environment so that it can increase the value and thinking ability of students [11].

The second stage is the Individual Readiness Assurance Test (IRAT), at this stage students will be given individual tests in the form of multiple choice. IRAT is an important stage, because this test will be used to assess students' readiness in learning and class discussion. This process will encourage students to better master the material, increase the responsibility and motivation of each individual to participate in group discussions [26].

The third stage is the Team Readiness Assurance Test (TRAT), where students will take the same test as IRAT but do it in groups. The purpose of using the same test is to improve students' ability to remember material and understanding [13].The group discussion process that occurs during TRAT will help students to get information, understand basic concepts, improve communication skills and correct misunderstandings of concepts that might arise during the learning [3].At this stage special answer sheets are used in the form of scratch-off answer cards that function to provide direct feedback. The use of answer sheets is able to increase the involvement of students in the discussion process [23].Increasing the involvement of students in the discussion process will also improve students' critical thinking skill. Involvement of students in learning groups will increase their understanding and critical thinking skills compared to students who study independently [1].

In the third stage students are also asked to write down the reasons for selecting group answers. Writing these reasons also affects the increase in students' critical thinking skill where by writing students will be trained in their ability to give good reasons. This is in accordance with the statement of Bustami, Riyati \& Julung who state that writing activities will require a person to have a good reason in thinking about the things they will write so that this activity will affect their critical thinking skills [4].

The fourth stage is Appeals at this stage students will write difficult questions that arise during the discussion process. This stage is able to improve students' critical thinking skills because when students receive specific and timely feedback it will help improve students' thinking abilities deeper and more critical [2]. The fifth stage is the Mini Lecture Clarification, where at this stage the teachers will provide corrections or additional explanations on concepts that are still not understood by students.

The last stage is Application. At this stage students are required to apply the concepts that have been learned. At this stage students will be given a case study that will be done in groups and presented in front of the class to get the best answer. This stage is able to improve students' critical thinking skills because the case studies provided are designed to be able to stimulate students to have a deep and critical discussion. The case studies provided are based on four criteria, namely Significant, Specific, Same Problem and Simultaneous reporting [11].

The Team Based Learning (TBL) model has several advantages including being able to teach students the skills 
of working in teams, communication, and problem solving [22].Styron, also argues that the Team Based Learning model can improve students' reasoning, the ability to think scientifically, think critically, and develop students' in-depth understanding of a material [23].

The score of students' critical thinking skills of the control class is lower than experiment class. This is caused by several factors such as the questions that arise during the learning process having not focused students to develop their critical thinking skills, the lack of application of concepts during the learning process, and the absence of direct feedback given to students.

\section{Conclusions}

The t-testshowedthatSig value $<0.05$. Based on the resultit can be concluded that there is an effect of Team Based Learning (TBL) model on students' critical thinking skills in Ecosystem topic. That is because Team Based Learning (TBL) model has the adventages including being able to teach students the skills of working in teams, communication, and problem solving, improve students' reasoning, the ability to think scientifically, think critically, and develop an in-depth understanding of a material.

\section{REFERENCES}

[1] Agogo, A. (2015). Implementing Team-Based Learning in principles of biology to determine effects on students' content knowledge, thinking skills, and attitudes about teamwork. Texas Woman's University, ProQuest Dissertations Publishing

[2] Ahn, H., Rotgans, J., Rajalingam, P., Lee, J., Koh, Y., \& Low-Beer, N. (2017). Assessing How Students Learn in Team-Based Learning: Validation of the Knowledge Re-Consolidation Inventory. Health Professions Education, 3(2), 118-127. doi: 10.1016/j.hpe.2017.10.001

[3] Alwahab, A., Abdulqader, S., Nugud, A., Nugud, S., Cyprian, F., Shaikh, A., \& Anwar, K. (2018). Team-based learning in an undergraduate pathology curriculum and its effects on student performance. Journal of Taibah University Medical Sciences, 13(5), 496-501. doi: 10.1016/j.jtumed.2018.03.010

[4] Bustami, Y., Riyati, Y., \&Julung, H. (2019). Think talk write with pictured cards on human digestive system: impact of critical thinking skills. Biosfer: Jurnal Pendidikan Biologi, 12(1), 13-23. doi: 10.21009/biosferjpb.v12n1.13-23

[5] Miarsyah, M., Ristanto, R.H., Nurhayati, Mufida, S.N., Suparini, Zharroh, A.E. (2020). Development of adobe flash media integrated into hots on circulation system (af-hots bicycle media). International Journal of Advanced Trends in Computer Science and Engineering, 9(1), 896-903. https://doi.org/10.30534/ijatcse/2020/128912020
[6] Chaeruman, A. U. (2018). Pembelajaran Abad 21. Prosiding Seminar Nasional Pembelajaran Abad 21. Jakarta 27 April 2018

[7] Lestari, P., Ristanto, R., \& Miarsyah, M. (2019). Analysis of Conceptual Understanding of Botany and Metacognitive Skill in Pre-Service Biology Teacher in Jakarta, Indonesia. Journal for the Education of Gifted Young Scientists, 7(2), 199-214. https://doi.org/10.17478/jegys.515978

[8] Ennis, R. H. (1985). A Logical Basis for Measuring Critical Thinking Skills. USA: University of Illinois.

[9] Facione, P. (2015). Critical Thinking: What It is and Why It Counts (pp. 1-30). Pearson Education

[10] Huggins, C., \&Stamatel, J. (2015). An Exploratory Study Comparing the Effectiveness of Lecturing versus Team-based Learning. Teaching Sociology, 43(3), 227-235. doi: $10.1177 / 0092055 \times 15581929$

[11] Supriyatin, Rahayu, S., Ristanto, R.H., \& Ichsan, I.Z. (2019). Improving hots in biology learning: A supplement book of plant growth and development. Universal Journal of Educational Research, 7(12), 2642-2646

[12] Ristanto, R. H,. Miarsyah, M., Muharomah, D.R., Astuti, T.A., Aini, S., \& Prihatin., A.I (2019). Light-Board: simple media to learn photosynthesis concepts. International Journal of Advanced Trends in Computer Science and Engineering, 9(1), 299-303. https://doi.org/10.30534/ijatcse/2020/45912020

[13] Macke, C., Taylor, J., Taylor, J., Tapp, K., \& Canfield, J. (2015). Social Work Students' Perceptions of Team-Based Learning. Journal Of Teaching In Social Work, 35(5), 454-470. doi: 10.1080/08841233.2015.1090520

[14] Leasa, M., Sanabuky, Y. L., Batlolona, J. R., \& Enriquez, J. J. (2019). Jigsaw in teaching circulatory system: a learning activity on elementary science classroom . Biosfer: Jurnal Pendidikan Biologi, 12(2), $122 \quad$ - 134 https://doi.org/10.21009/biosferjpb.v12n2.122-134

[15] Michaelsen, L., \& Sweet, M. (2011). Team-based learning. New Directions for Teaching and Learning, (128), 41-51. doi: 10.1002/tl.46

[16] Miharja, F. J., Hindun, I., \&Fauzi, A. (2019). Critical thinking, metacognitive skills, and cognitive learning outcomes: a correlation study in genetic studies. Biosfer: Jurnal Pendidikan Biologi, 12(2), 135 - 143. https://doi.org/10.21009/biosferjpb.v12n2.135-14

[17] Nafsiah, N. K., Zubaidah, S., \&Sulasmi, E. S. (2018). Critical Thinking Skills of High Boarding School Students in Malang. The 8th Annual Basic Science International Conference. 595-600

[18] Nosich, G. (2009). Learning to think things through: A guide to critical thinking across the curriculum. New Jersey: Pearson Education, Ltd

[19] Pelech, J., \& Pieper, G. (2010). The Comprehensive Handbook of Constructivist Teaching: From Theory to Practice. New York: Information Age Publishing.

[20] Permana, F. H., \&Chamisijatin, L. (2019). Project-based learning through edmodo: improving critical thinking and histology concepts. Biosfer: Jurnal Pendidikan Biologi, 12(1),

58-69. 
https://doi.org/10.21009/biosferjpb.v12n1.58-69

[21] PISA. (2018). PISA 2018 result. (Online). https://www.oecd.org/pisa/PISA/202018/20Insights/20and/ 20Interpretations/20FINAL/20pdf (Accessedonseptember 2018)

[22] Reimschisel, T., Herring, A., Huang, J., \& Minor, T. (2017). A systematic review of the published literature on team-based learning in health professions education. Medical Teacher, 39(12), 1227-1237. doi: 10.1080/0142159x.2017.1340636

[23] Styron, R. A. (2014). Critical Thinking and Collaboration: A Strategy to Enhance Student Learning. Systemics Cybernetics and Informatics. (12(7), 25-30

[24] Sukiniarti. (2016). Improving Science Pedagogic Quality in Elementary School Using Process Skill Approach Can Motivate Student to Be Active in Learning. Journal of Education and Practice, 7(5), 150-157.

[25] Djamahar, R., Ristanto, R. H., Sartono, N., Ichsan, I. Z., Darmawan, E., \&Muhlisin, A. (2019). Empowering Student's Metacognitive Skill Through Cirsa Learning. In Journal of Physics: Conference Series (Vol. 1227, p. 12034). Malang. https://doi.org/10.1088/1742-6596/1227/1/012034

[26] Zubaidah, S., Corebima, A. D., Mistianah (2015). AsesmenBerpikirKritisTerintegrasiTes Essay. Proceeding Symposium on biology education. Universitas Ahmad Dahlan, Yogyakarta, 4-5 April 2015 